\title{
THE EFFECT OF SERVICE QUALITY ON THE LEVEL OF SATISFACTION FOR MAKING LAND CERTIFICATE IN BONDOWOSO REGENCY
}

\author{
Eka Zerli Defintasari ${ }^{1}$ \\ Muhammad Firdaus ${ }^{2}$ \\ Hary Sulaksono ${ }^{3}$ \\ Student of Magister Management Program \\ Higher Education of Economic Mandala \\ Email: ekazerly@gmail.com
}

\begin{abstract}
This study aims to determine the quality of service to the satisfaction of the community in making the Land Certificate in the Land Office of Bondowoso district. This research was conducted at the Land Office, Bondowoso Regency. The population in this study is the Bondowoso community. The sampling method uses simple random sampling with questionnaire distribution techniques. The number of samples in this study were 55 respondents, namely applicants who came directly to the Land Office of Bondowoso Regency. The data analysis method in this study uses the Importance Performance Analysis (IPA) analysis and the Customer Satisfaction Index. Based on the results of data analysis, the variable with the largest gap in the Empathy Dimension is the gap value of -0.38 and the estimated gap is -0.1 in the Guarantee Dimension. This result also shows that the indicators of quality of certificate-making services whose level of importance is in accordance with the community are above average but are better than expected.
\end{abstract}

Keywords: Service Quality, Public Satisfaction, Land Certificate

\section{INTRODUCTION}

Service basically can be defined as the activity of a person, group, and organization either directly or indirectly to meet needs. Service means serving a service needed by society in all fields. Public service activities are one of the duties and functions of state administration. According to (Sinambela, 1997) states that service is the provision of services (serving) the needs of people or communities who have an interest in the organization by the basic rules and procedures that have been determined.

The National Land Agency as a nonministerial institution is a public service institution that is authorized to provide services to the community in terms of land services based on Presidential Regulation of the Republic of Indonesia No. 10 of 
2006 concerning the National Land Agency. (Presiden Republik Indonesia, 2006). The land certification service has an important meaning for the community, which is a guarantee and legal certainty as well as legal protection for a plot of land for the landowner. The excess of a certificate with other written evidence is a strong proof of rights.

The land has strategic value and important value in the human context and the dynamics of development, so in the 1945 Constitution article 33 paragraph 3 it is stated that the land and water and natural resources contained in it are controlled by the State and used for the greatest prosperity of the people. Provisions regarding land are also contained in the Law of the Republic of Indonesia No. 5 of 1960 concerning Basic Agrarian Principles (UUPA). (The Republic Of Indonesia, 1960). Furthermore, land registration is regulated through Government Regulation No. 24 of 1997 concerning Land Registration. Article 1 point 1 states that land registration is a series of activities carried out by the government continuously, continuously, and regularly including the collection, processing, bookkeeping, and presentation and maintenance of physical and juridical data in the form of maps and lists of land parcels and units. flat, including issuing a certificate of proof of rights and ownership of apartment units and certain rights that impose it (Pemerintah Republik Indonesia, 1997). This land registration avoids disputes over land rights and guarantees legal certainty and protection for its owners. Land disputes caused by problems with other people's recognition of their land can be reduced if the land has been registered with the Land Office.

The real manifestation of public service problems can be seen in the service of making land certificates. To accelerate land registration, the Bondowoso Regency National Land Agency is currently implementing a national program called Complete Systematic Land Registration
(PTSL). PTSL is a registration activity for the first time that is carried out simultaneously and includes all land registration objects that have not been registered in a village or sub-district area (Ardani, 2019)

By the Regulation of the Minister of Agrarian and Spatial Planning / Head of the National Land Agency number 35 of 2016 concerning the Acceleration of Implementation of Complete Systematic Land Registration, the national program which was started in 2017, with a target of 5 million land parcels, in 2018 with a target of 7 million land parcels, and by 2019, with a target of 9 million land parcels. "So, until 2025, all land and land in Indonesia has been certified. (Permen ATR/KBPN Nomor 35, 2016). Certificates as strong evidence can provide legal certainty for both the subject and the object.

Bondowoso Regency is one of the districts in Indonesia that also supports the Accelerated Implementation of Complete Systematic Land Registration program. For Bondowoso Regency, especially in 2019, it is targeting as many as 25 thousand land parcels to be registered and certified. The land that is targeted is spread over 24 villages in 6 sub-districts. These subdistricts are Tamanan, Curahdami, Grujugan, Sukosari, Pakem, and Pujer Districts. Efforts to implement this program have been carried out by the Bondowoso District Land Office. However, the implementation of this program has not been followed by the availability of good service facilities. The facilities for managing land certificates are not carried out systematically and there are no online registration and management facilities for certificates so that many people carry out sporadic arrangements and not even a few people use the services of making certificates instead of managing themselves. This is of course contrary to the objectives of the government's Complete Systematic Acceleration of Land Registration (PTSL) program. Besides, until now there have been many complaints 
from the public regarding the quality of services provided by the Bondowoso Regency Land Service, such as long and convoluted land management procedures. As a result, many people choose to use certificate making services such as those offered by village officials themselves or from PPAT. The use of this service certainly adds to the cost burden for the community to obtain proof of ownership of their land and this fee is relatively expensive compared to managing it themselves. Therefore, the community demands the Bondowoso Branch of the National Land Agency to improve the quality of services by providing facilities for the community to arrange for a certificate.

Public service issues should always pay attention to their consumer complaints by improving service quality or by being professional in the public service process. (Sulistyowati, 2014) states that service quality consisting of responsiveness, reliability, assurance, empathy, and tangible has an effect on customer satisfaction where the reliability variable has the strongest influence compared to other variables. Besides (Hermawan, Hakim, \& Hutagaol, 2016) stated that the dimensions of service quality as a whole have not met community satisfaction, so there is a need for adjustments to standard service requirements, evaluate and review existing policies and are no longer relevant to current conditions.

The quality of service greatly affects the capacity of the community as service recipients. If the level of service quality is getting better, the level of community satisfaction is getting better. This is currently the priority for service providers or public agencies in providing public services to the community. This study aims to determine the attributes of service quality dimensions that have met the satisfaction of the people of Bondowoso Regency and to know the attributes of service quality dimensions that need to be improved to achieve the level of satisfaction desired by the people of Bondowoso Regency. The results of this study are expected to reveal further about community satisfaction with performance and to find out what dimensions affect the Bondowoso Regency Land Office in terms of making Land Certificates to be a better land service improvement for Bondowoso Regency Land Office.

Several studies on the effect of service quality on community satisfaction have been conducted by previous researchers. (Sulistyowati, 2014) states that service quality which consists of responsiveness, reliability, assurance, empathy, and tangible has an effect on customer satisfaction where the reliability variable has the strongest influence compared to other variables. Besides, (Sinaga \& Hidayat, 2016) stated that tangible and empathy dimensions affect public satisfaction. The same thing was also expressed by (Mahardika, 2012) who stated that the variable service quality consisting of variables of physical evidence, reliability, responsiveness, assurance, and empathy was positive and had a significant effect on community satisfaction in the Kenjeran District Office, Surabaya. (Despriyatmoko, Syarief, \& Maulana, 2016) stated that the dimensions of service quality in maintaining land registration data show that as a whole the community is satisfied with the quality of service at the Bogor Regency Land Office. Besides (Hermawan et al., 2016) stated that the dimensions of service quality as a whole have not met community satisfaction, so it is necessary to adjust service requirements standards, evaluate and review existing policies that are no longer relevant to current conditions. The 
same thing was also expressed by (Widuri, 2016) that the five dimensions studied were still some obstacles, namely the reliability dimension which was indicated by not all officers being able to operate the computer properly, responsiveness was related to the officers' inaccuracy in examining the applicant's file, and an assurance was indicated related issuance of certificates that often exceed the specified time target. (Paris, 2014) states that service quality has a significant effect on community satisfaction, the same thing is also expressed by (Kusumaningtyas \& Sediyono, 2017); (Rahmania, 2019); (Miranti, 2013) and (nurhidayati dan Silpia, 2018) which state that service quality affects community satisfaction.

Service quality according to Kep. Men. PAN Number 63 / KEP / M.PAN / $7 / 2003$ means that the quality of service is closely related to the certainty of procedures, time, and transparent and accountable financing which must be carried out completely by every agency and service unit of government agencies according to their overall duties and functions. . If the quality of services provided by service providers reaches the expectations of service recipients or the community, the quality of these services will be considered good and vice versa. If the quality of service provided by service providers has not reached the expectations of service recipients or the community, then the quality of this service will be considered unsuccessful. ((Kementerian Pendayagunaan Aparatur Negara Republik Indonesia, 2003)

According to Lukman in (Desthiani, 2020) Satisfaction is defined as "the level of a person's feelings or the gap between the expectations or desires of consumers and the reality they experience. Regulation of the Minister of State Apparatus Empowerment and Bureaucratic Reform of the Republic of Indonesia Number 14 of 2017 concerning Guidelines for Preparing Community Satisfaction Surveys for Public Service Provider Units. The elements of the
Community Satisfaction Survey in this regulation include requirements; Systems, Mechanisms and Procedures; Completion Time; Fees / Rates; Product specification type of service; Implementing Competencies; Implementing Behavior; Handling complaints, suggestions, and input; and Facilities and infrastructure. (Kementerian Pendayagunaan Aparatur Negara RI, 2017).

In this study, the researcher used the service quality variable as the independent variable and the community satisfaction variable as the dependent variable. Service quality is the main foundation of community satisfaction. People who are satisfied with a service will instill a positive image and spread the good news by word of mouth. On the other hand, dissatisfaction with a service will encourage the public to do negative publicity and this is certainly not good for a public service institution that serves the needs of the community. Based on the description above, the hypothesis in this study is that it is suspected that service quality has a significant effect on community satisfaction at the Bondowoso Regency Land Service.

\section{RESEARCH METHODS}

The place of research is the place where this research is carried out. In this study, researchers took the research location at the Bondowoso Regency Land Office, Jalan Imam Bonjol No. 05 Bondowoso. When the research was carried out from January to December 2018. The population of this study was the Land Certificate Maker Society who came directly to the Bondowoso Regency Land Office, the total population of Bondowoso Regency in 2018 was 791,838 people, consisting of 394,883 male residents and 396,955 residents. women spread across 23 districts. To determine how large the sample size is as a representative of the population, researchers use the Slovin Formula guidelines (Sugiyono, 2011) as follows: 


$$
\begin{aligned}
& n=\frac{115}{1+115(10 \%)^{2}} \\
& n=53,48
\end{aligned}
$$

Based on the above calculations, the sample taken as many as 55 (rounded) people who came to the Bondowoso Regency Land Office, this was done to facilitate data processing and for better test results. The sampling technique used in this research is simple random sampling technique is taking the sample members from the population which is done randomly without paying attention to the existing strata in the population. Thus every element of the population must have the same opportunity to be selected to be the sample. (Sugiyono, 2014)

Based on the problem formulation and research objectives, the type of research used is explanatory research. This study aims to test a theory or hypothesis to strengthen or even reject existing theories or research hypotheses. Explanatory research is used to explain the relationship between research variables, concepts and to test several hypotheses. The approach used in this research is quantitative. (Malhotra, Birks, \& Wills, 2012).

The data sources of this research are internal and external. Where the source of internal data was obtained by researchers from the Bondowoso Regency Land Office. Meanwhile, external data sources were obtained by researchers from consumers and data obtained from internet media, journals, books, and theses from libraries.

The validity test in this study was determined by correlating the scores obtained by each question or statement with the total score. The total score is the sum of all the scores for the question or statement. A research instrument is said to be valid or false if it has high validity. The data instrument test also uses the reliability test which aims to determine the level of stability of a measuring instrument.
Malhotra in (Amin, Dimyati, \& Firdaus, 2016)

The data analysis method uses Importance Performance Analysis (IPA) and assesses the Customer Satisfaction Index (CSI) to determine the overall level of visitor satisfaction with an approach that considers the importance of the attributes being measured. This analysis links the importance level of an attribute of a particular object to the reality (performance) perceived by the user. (Berry, Zeithaml, \& Parasuraman, 1988)

\section{RESULTS ANALYSIS}

Importance Performance Analysis method is an analysis that links the importance level of an attribute of a particular object to the reality that is felt by the user. (Berry et al., 1988).. The first step is to determine the suitability between the level of service quality and community satisfaction of each attribute through a score comparison, as follows:

$$
\begin{aligned}
T k i & =\frac{X i}{Y i} \times 100 \% \\
T k i & =\frac{5903}{5966} \times 100 \%=98.94 \%
\end{aligned}
$$

Information :

Tki: Level of Conformity

Xi: Service Quality Assessment Score

Yi: Community Satisfaction

Assessment Score

The results of the Cartesian diagram from this study are as follows: 


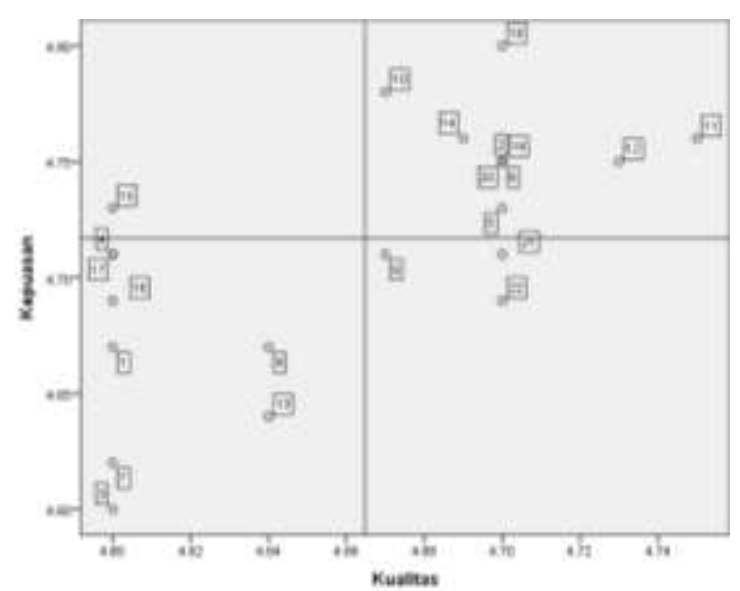

Figure 1. Cartesian diagram

The dimensions used to measure community satisfaction (Y) at the Bondowoso Regency Land Office towards service quality are based on dimensions consisting of five dimensions, namely Physical Evidence $\left(\mathrm{X}_{1}\right)$, Reliability $\left(\mathrm{X}_{2}\right)$, Responsiveness $\left(\mathrm{X}_{3}\right)$, Assurance $\left(\mathrm{X}_{4}\right)$, and Empathy $\left(\mathrm{X}_{5}\right)$.

\section{INTERPRETATION}

Based on the results of the research, the dimensions of service quality which are the main priority in this study are attributes $\left(\mathrm{X}_{1.1}\right)$, namely the community is dissatisfied with the physical facilities used by the counter officers at the Land Office of Bondowoso Regency which are up to date. This is indicated by the results of the Cartesian diagram which shows the results of the quality level of 4.6 and the satisfaction level of 4.73 so that they are in Quadrant I position. Most of the applicants who come directly are aged 38 years and over and are men who do not understand the system used by the Land Office. Bondowoso Regency.

Based on the results of the research, the dimensions of service quality that need to be maintained in this study are attributes (X1.2) physical facilities (chairs, tables, brochures, large parking facilities), (X2.2) Clarity of service information provided by counter officers in making certificates, (X2.3) Accuracy of document inspection requirements for certificate production, (X3.3) Officers act fast in service to applicants, (X3.4) Officers are polite in serving applicants, (X4.2) Officers who can provide security to the applicant, (X4.4) Knowledgeable officers to answer the applicant's questions, (X5.4) Officers who understand the specific needs in making certificates, (Y1.1) Attitude officers towards services, and (Y1.2) Officers' speed towards service to the applicant. This is shown by the results of the Cartesian diagram showing the quality level results of $4.7-4.8$ and the satisfaction level of 4.75 4.76 so that they are in quadrant II position, this data is also supported by the answers of respondents who on average choose very important answers. and very satisfying services provided by the Bondowoso Regency Land Office.

Based on the results of the research, the dimensions of service quality which are the low priority choices in this study are attributes (X1.1) The equipment used by the counter clerk, (X1.3) The ticket office clerk is neat (using uniforms and attributes according to the provisions), (X2.1) Timeliness of completion of Certificate making, (X2.4) Counter clerk is sympathetic and able to calm customers whenever there is a problem, (X3.1) Officers who are responsive and alert in following up on complaints experienced by applicants, (X4.3) Officers are honest and can be trusted with the needs of the applicant, (X5.2) Timeliness of service (working hours) that is suitable/comfortable for the applicant, and (X5.3) the Land Office of Bondowoso Regency which really pays attention to the completion of each applicant's Certificate. This is indicated by the results of the Cartesian diagram showing the results of the quality level of 4.6 and the level of satisfaction of 4.62 - 4.67. This data is supported by the results of interviews and questionnaires, most applicants do not want too much ado in service, the applicant wants results following their expectations, namely fast, precise, responsive, and wants to take precedence in serving the applicant, while the office itself has Standard Operating Procedures (SOP). and the specified 
certificate completion flow. Thus in this study is different from previous studies using Importance Performance Analysis (IPA) and Customer Satisfaction Index (CSI) to better know which variables need to be maintained and improved in this study and the selection of these analyzes is by the phenomena on the research object.

Based on the results of the research, the dimensions of service quality that are excessive in this study are the attributes (X3.2) of the officer being fast in conveying information on making certificates, (Y1.3) The accuracy of the officer with the services provided to the applicant and (Y1.4) the Petitioner recommending the servant. This is indicated by the results of the Cartesian diagram showing the results of the quality level of $4.67-4.7$ and the quality of satisfaction of $4.69-4.71$, from the interview and questionnaire data that the customer is satisfied with the service of the Bondowoso Regency Land Office so that this attribute is felt not so important by the applicant.

The results of this study support the findings of research conducted by (Tamara, Mananeke, \& Kojo, 2018) which states that service quality has a significant effect on community satisfaction. The same thing was also expressed in the findings of research conducted by (Nurvadila, 2014) and (Ulumudin, 2014). Besides, this study also supports the findings of research conducted by (Dahmiri \& Suzana, 2013) and (Susila, 2010) which state that service quality has a significant effect on community satisfaction.

Based on the findings in the field, the Bondowoso district land office should provide massive information to the people of Bondowoso about the procedures and completeness of the requirements and urge them to immediately register their land until it becomes a certificate. With the delivery of information and appeals to the public, it is hoped that the process of making certificates and certificates can be completed on time. This should also be supported by the performance of Bondowoso Land Office employees to be able to work according to the applicable SOP. By improving the above matters, it can help the workload of employees and be able to complete the work according to the time that has been determined in the completion of making land certificates. So that the applicant does not have to wait too long to get the certificate that has been submitted if the public understands the procedures and flow and is supported by employees who can work according to the procedures and time set by the regulations. This can also change the public's view of the Bondowoso Regency Land Office services which are known for a long time in making certificates.

\section{CONCLUSION}

Based on the results of the analysis from the previous chapter, the following conclusions can be drawn and some suggestions that may be used as reference and consideration in improving the quality of existing services in the Bondowoso Regency Land Office. Based on the results of the research, the dimensions of service quality that are excessive in this study are the attributes of officers being fast in conveying information on making certificates, the accuracy of officers to the services provided to the applicant, and the applicant recommending the servants. The results of the Cartesian diagram show the results of the quality level of $4.67-4.7$ and the quality of satisfaction from 4.69 to 4.71 . This shows that the community is satisfied with the service performance of the Bondowoso Regency Land Office, but the performance given has not been optimal. 


\section{REFERENCES}

Amin, S., Dimyati, M., \& Firdaus, M. (2016). Pengaruh Citra Perusahaan Dan Citra Pemakai Terhadap Keputusan Pembelian Jasa Perbankan Syariah Di Jember. RELASI : JURNAL EKONOMI, 12(1), 501-518. https://doi.org/https://doi.org/10.31967 /relasi.v12i1.90

Ardani, M. N. (2019). Peran Kantor Pertanahan dalam Kegiatan Pendaftaran Tanah Sistematis Lengkap. Gema Keadilan, 6(1), 44. https://doi.org/10.14710/gk.6.1.44-62

Berry, L. L., Zeithaml, V. A., \& Parasuraman, A. (1988). Communication and Control Processes in the Delivery of Service Quality. [s.1]: [s.n].

Dahmiri, \& Suzana, V. (2013). Pengaruh Kualitas Pelayanan Terhadap Kepuasan Masyarakat Pada Dinas Kependudukan Dan Pencatatan Sipil Kabupaten Sarolangun. Jurnal Manajemen Terapan Dan Keuangan, 84, 487-492. Retrieved from http://ir.obihiro.ac.jp/dspace/handle/10 $322 / 3933$

Despriyatmoko, G., Syarief, R., \& Maulana, A. (2016). Tingkat Kepuasan Terhadap Kualitas Pelayanan Pemeliharaan Data Pendaftaran Tanah Di Kantor Pertanahan Kabupaten Bogor. Jurnal Aplikasi Bisnis Dan Manajemen, 2(2), 172-182.

https://doi.org/10.17358/jabm.2.2.172

Desthiani, U. (2020). Peran Pelayanan Prima Kasir Terhadap Kepuasan Pelanggan Pada Pt Aeon Indonesia Tangerang. Jurnal Sekretari Universitas Pamulang |, 7(1).

Hermawan, W., Hakim, D. B., \& Hutagaol, M. P. (2016). Analisis Kepuasan Masyarakat terhadap Kualitas Pelayanan dalam Pendaftaran Tanah Pertama kali Pada Kantor Pertanahan Kabupaten Bogor. Jurnal Ilmu Keluarga Dan Konsumen, 9(1), 6575 . https://doi.org/10.24156/jikk.2015.9.1. 65

Indonesia, Pemerintah Republik. (1997). Peraturan Pemerintah Republik Indonesia Nomor 24 Tahun 1997 Tentang Pendaftaran Tanah. 1-26.

Indonesia, Presiden Republik. (2006). Peraturan Presiden Republik Indonesia Nomor 10 Tahun 2006 Tentang Badan Pertanahan Nasional. https://doi.org/10.16258/j.cnki.16745906.2006.01.022

Kementerian Pendayagunaan Aparatur Negara Republik Indonesia. (2003). Keputusan Pendayagunaan Aparatur Negara Nomor : 63/KEP/M.PAN/7/2003 Tentang Pedoman Umum Penyelenggaraan Pelayanan Publik (p. 21). p. 21.

Kementerian Pendayagunaan Aparatur Negara RI, P. M. (2017). Permenpam No, $14 \quad$ Tahun 2017. https://doi.org/10.1161/01.STR.32.1.1 39

Kusumaningtyas, J. A., \& Sediyono, E. (2017). Analisis Kepuasan Pelanggan Pembuatan Sertifikat Tanah Dengan Menggunakan Servqual Dan Kansei Engineering Berdasarkan Twitter BPN Salatiga. Jurnal Teknologi Informasi Dan Ilmu Komputer, 4(3), 154-159. https://doi.org/10.25126/jtiik.2017433 29

Mahardika. (2012). Pengaruh Kualitas Layanan Terhadap Kepuasan Masyarakat di Kantor Kecamatan Kenjeran Surabaya. Dinamika Administrasi Bisnis, 107-124.

Malhotra, N. K., Birks, D. F., \& Wills, P. (2012). Marketing research: an applied approach. Harlow: Pearson Education.

Miranti, S. A. (2013). Studi Tentang Pelayanan Pembuatan Ktp. Journal Administrasi Negara, 1(1), 68-81.

nurhidayati dan Silpia, R. 2018. (2018). Pelayanan Pendaftaran Tanah Sistematis Lengkap (PTSL) Terhadap Kepuasan Masyarakat Pada Badan Pertanahan Nasional Kabupaten 
Bekasi. Widya Cipta - Jurnal Sekretari Dan Manajemen, 2(2), 279-284. Retrieved from http://ejournal.bsi.ac.id/ejurnal/index.p $\mathrm{hp} /$ widyacipta/article/view/4419/2688

Nurvadila. (2014). Pengaruh Kualitas Pelayanan Terhadap Kepuasan Pemohon KTP-el Pada Kantor Dinas Kependudukan dan Pencatatan Sipil Kabupaten Luwu. Jurnal Ilmu Administrasi Negara, 1(1).

Paris, Y. (2014). Pengaruh Pelayanan Bidang Penerbitan Sertifikat Tanah Terhadap Kepuasan Masyarakat Pada Kantor Badan Pertanahan Nasional Kota Makassar. Jurnal Ilmiah Ilmu Administrasi Publik, 4(1), 65-83. https://doi.org/10.26858/jiap.v4i1.182 1

Permen ATR/KBPN Nomor 35. (2016). Peraturan Menteri ATR/Kepala BPN Nomor 35 Tahun 2016 tentang Percepatan Pelaksanaan Pendaftaran Tanah Sistematik Lengkap (PTSL). Retrieved from http://www.bpn.go.id/PUBLIKASI/Pe raturan-Perundangan

Rahmania, D. (2019). Pengaruh kualitas pelayanan loket pendaftaran terhadap kepuasan masyarakat di kantor pertanahan kabupaten bogor 1). 10(1), 91-100.

Sinaga, J., \& Hidayat, R. (2016). Pengaruh Kualitas Pelayanan Terhadap Kepuasan Masyarakat Dalam Pelaksanaan Program Pelayanan Administrasi Terpadu Kecamatan. Jurnal Akuntansi, Ekonomi Dan Manajemen Bisnis, 4(1), 7-14.

Sinambela, P. (1997). Birokrasi (Suatu Tinjauan Perilaku Birokrasi). Widya: Majalah Ilmiah, 14(147), 21.

Sugiyono. (2011). Statistika untuk penelitian. Bandung: Alfabeta.

Sugiyono, P. D. (2014). Populasi dan sampel. Metode Penelitian Kuantitatif, Kualitatif Dan R\&D, (April 1952), 80.

Sulistyowati, E. (2014). Analisis Pengaruh Kualitas Pelayanan Badan Pertanahan Nasional (BPN) terhadap Kepuasan Masyarakat di Daerah Istimewa Yogyakarta. Jurnal Maksipreneur: Manajemen, Koperasi, Dan Entrepreneurship, 4(1), 48. https://doi.org/10.30588/jmp.v4i1.95

Susila, L. N. (2010). Analisis Pengaruh Kualitas Pelayanan Kantor Kelurahan Terhadap Kepuasan Masyarakat Kelurahan Jagalan Kecamatan Jebres Kota Surakarta. Journal of Rural and Development, 1(1), 63-72.

Tamara, N. I. ., Mananeke, L., \& Kojo, C. (2018). Minahasa Selatan the Effect of Service Quality Against Kawangkoan Communities Under Kecamatan Amurang Barat in Minahasa Selatan District. Jurnal Emba, 6(4), 35233532.

The Republic Of Indonesia, G. (1960). Law of Republic of Indonesia Number 5 of 1960 Concerning Basic Regulation for Agrarian Principle (Basic Agrarian Law). (5), 1-34.

Ulumudin, A. (2014). Pengaruh Kualitas Pelayanan Administrasi Kependudukan terhadap Kepuasan Masyarakat di Kecamatan Bayongbong Kabupaten Garut. Jurnal Pembangunan Dan Kebijakan Publik, 04(01), 1-6.

Widuri, A. R. (2016). Analisis Kualitas Pelayanan Pembuatan Sertifikat Tanah di Kantor Badan Pertanahan Nasional Kabupaten Semarang. Journal of Public Policy and Management Review, 5(4), 368. 